\title{
Integrated analysis of the miRNA, gene and pathway regulatory network in gastric cancer
}

\author{
HAIYANG ZHANG $^{1 *}$, YANJUN QU $^{1 *}$, JINGJING DUAN $^{1 *}$, TING DENG $^{1 *}$, RUI LIU $^{1}$, LE ZHANG $^{1}$, \\ MING BAI ${ }^{1}$, JIALU LI ${ }^{2}$, LIKUN ZHOU ${ }^{1}$, TAO NING ${ }^{1}$, HONGLI LI $^{1}$, SHAOHUA GE $^{1}$, \\ HUA LI $^{1}$, GUOGUANG YING ${ }^{1}$, DINGZHI HUANG ${ }^{1}$ and YI BA $^{1}$ \\ ${ }^{1}$ Tianjin Medical University Cancer Institute and Hospital, National Clinical Research Center for Cancer, \\ Key Laboratory of Cancer Prevention and Therapy, Tianjin 300060; \\ ${ }^{2}$ Department of Gastroenterology, Tianjin First Center Hospital, Tianjin 300192, P.R. China
}

Received October 9, 2015; Accepted October 26, 2015

DOI: 10.3892/or.2015.4451

\begin{abstract}
Gastric cancer is one of the most common malignant tumors worldwide; however, the efficacy of clinical treatment is limited. MicroRNAs (miRNAs) are a class of small noncoding RNAs that have been reported to play a key role in the development of cancer. They also provide novel candidates for targeted therapy. To date, in-depth studies on the molecular mechanisms of gastric cancer involving miRNAs are still absent. We previously reported that 5 miRNAs were identified as being significantly increased in gastric cancer, and the role of these miRNAs was investigated in the present study. By using bioinformatics tools, we found that more than 4,000 unique genes are potential downstream targets of gastric cancer miRNAs, and these targets belong to the protein class of nucleic acid binding, transcription factor, enzyme modulator, transferase and receptor. Pathway mapping showed that the targets of gastric cancer miRNAs are involved in the MAPK signaling pathway, pathways in cancer, the PI3K-Akt signaling pathway, the HTLV-1 signaling pathway and Ras signaling pathway, thus regulating cell growth, differentiation, apoptosis and metastasis. Analysis of the pathways related to miRNAs may provides potential drug targets for future therapy of gastric cancer.
\end{abstract}

Correspondence to: $\mathrm{Dr} \mathrm{Yi} \mathrm{Ba}$ or Dr Dingzhi Huang, Tianjin Medical University Cancer Institute and Hospital, National Clinical Research Center for Cancer, Key Laboratory of Cancer Prevention and Therapy, Tianjin 300060, P.R. China

E-mail: bayi@tjmuch.com

E-mail: dingzhih72@163.com

*Contributed equally

Key words: miRNA, network, pathway, bioinformatic analysis, gastric cancer

\section{Introduction}

Gastric cancer is the second leading cause of cancer-related mortality worldwide and is the most common malignancy in China and Japan, affecting approximately one million individuals every year $(1,2)$. The highest ratio, up to 69 cases per 100,000 individuals per year, has been determined in males in Northeast Asia (3). Prevention and personalized treatment are regarded as the best options to reduce gastric cancer mortality rates. Gastric cancer is usually a result of a high intake of various traditional salt-preserved foods and salt, concomitant with a low consumption of fresh fruit and vegetables $(4,5)$. Analysis of the signaling pathways in cancer cells provides novel biomarkers for diagnosis and drug targets for treatment.

miRNAs are a novel class of small non-coding RNAs, typically 22 nucleotides in length (6). miRNAs suppress gene expression by directly binding to mRNAs, causing translation repression or mRNA cleavage $(7,8)$. They are single-stranded RNAs that negatively regulate gene expression at the post-transcriptional level $(6,9,8)$. Longer precursor transcripts with hairpin structures are first synthesized by RNA polymerase II, followed by processing of precursors by Drosha and Dicer. To date, miRNAs have been found to be involved in various physiological and pathological processes, including cell metabolism, tumorigenesis, cell growth and apoptosis, aging, organic development and the immune response $(10,11)$. A single RNA may have hundreds or more targets, therefore it is difficult to distinguish functions to specific miRNAs.

Studies have demonstrated that miRNAs can function as oncogenes or tumor suppressors by regulating the expression of cancer-related genes (12). During the latest decade, a set of cancer regulator miRNAs have emerged and these are divided into oncomiRs or anti-oncomiRs. Specific miRNA profiles have been observed in both tumor tissues and plasma in various types of cancers (13-16). These miRNAs are believed to be potential biomarkers for the diagnosis and may also support the prognosis or treatment of cancer (17). Recent projects have attempted to decipher the differential expression of miRNAs in specific cancers; however, the complex pathways comprising miRNAs and their target genes remain unclear. 
Identification of the molecular causes of cancer represents a major breakthrough in the history of medicine, moving the discipline from pattern recognition and therapeutic strategies based on molecular mechanisms and therapies derived from clinical trials (18). The development of pathway strategies for the analysis of gastric cancer makes it possible to use these approaches for future clinical treatment.

We previously reported that 5 significant miRNAs are overexpressed in gastric cancer and serve as a fingerprint for gastric cancer diagnosis (14). In the present study, the protein classes, molecular functions, biological functions and canonical pathways comprising the targets of each gastric cancer-related miRNA as well as four main canonical pathways were identified and analyzed, offering novel drug targets for gastric cancer therapy.

\section{Materials and methods}

Target prediction of gastric cancer $(G C)$-related miRNAs. A web-based software TargetScan (http://www.targetscan. org) was used to generate lists of possible gene targets of each miRNA (19). Then the targeted genes were inputted into another web server Panther (http://www.pantherdb.org/) which is designed for gene function cluster and we obtained the protein class from Panther analysis $(20,21)$. After that, we clustered the same functional class of protein in top ten classes.

The web-based functional annotation tool Database for Annotation, Visualization and Integrated Discovery (DAVID) v6.7 (http://david.abcc.ncifcrf.gov/tools.jsp) has key components for disease analysis, gene ontology analysis and pathway analysis (22).

Signaling pathway mapping of GC-related miRNAs. The signaling pathways and processes were explored using the systems biology tool KEGG Mapper (http://www.genome.jp/ $\mathrm{kegg} / \mathrm{tool} / \mathrm{map}$ _pathway2.html) which is a collection of tools for KEGG mapping: KEGG pathway mapping, BRITE mapping and MODULE mapping (23). The KEGG database consists of 16 main databases (systems information, KEGG PATHWAY, KEGG BRITE, KEGG MODULE, KEGG DISEASE, KEGG DRUG and KEGG ENVIRON; genomic information, KEGG ORTHOLOGY, KEGG GENOME, KEGG GENES, KEGG SSDB and KEGG; chemical information, KEGG COMPOUND, KEGG GLYCAN, KEGG REACTION, KEGG RPAIR, KEGG RCLASS and KEGG ENZYME).

\section{Results and Discussion}

$G C$-related miRNAs. Based on the experimental data in our previous study, 5 miRNAs were selected as GC-related miRNAs (Table I). These miRNAs were found to be clearly increased in GC, and their dysregulation is believed to promote tumorigenesis.

There are 2 different precursors of miR-1, miR-1-1 and miR-1-2 (24). It exists alone or with miR-133a to form a cluster. It is well known that miR-1 is a tumor-suppressive miRNA in various types of cancers including lung cancer, gastric cancer, colorectal cancer, prostate cancer, thyroid cancer, head and neck squamous cell carcinoma and rhabdomyosarcoma (25-30), the effects of which have been confirmed to
Table I. The predicted targets of GC-related miRNAs.

\begin{tabular}{lc}
\hline GC miRNAs & No. of predicted target genes \\
\hline miR-1 & 769 \\
miR-20a & 1,218 \\
miR-27a & 1,210 \\
miR-34a & 655 \\
miR-423-5p & 180 \\
\hline
\end{tabular}

Table II. Molecular function and biological process analysis of GC-related miRNAs.

\begin{tabular}{|c|c|c|}
\hline $\begin{array}{l}\text { GC } \\
\text { miRNAs }\end{array}$ & $\begin{array}{c}\text { Molecular function and } \\
\text { biological processes }\end{array}$ & $\begin{array}{c}\text { Regulated by } \\
\text { GC-miRNAs }(\%)\end{array}$ \\
\hline \multirow[t]{6}{*}{ miR-1 } & Binding & 34.40 \\
\hline & Catalytic activity & 27.40 \\
\hline & $\begin{array}{l}\text { Nucleic acid binding } \\
\text { transcription }\end{array}$ & 12.00 \\
\hline & Transporter activity & 6.40 \\
\hline & Enzyme regulator activity & 6.40 \\
\hline & Receptor activity & 6.40 \\
\hline \multirow{5}{*}{ miR-20a } & Binding & 35.80 \\
\hline & Catalytic activity & 28.60 \\
\hline & $\begin{array}{l}\text { Nucleic acid binding } \\
\text { transcription }\end{array}$ & 13.10 \\
\hline & Enzyme regulator activity & 6.80 \\
\hline & Receptor activity & 5.30 \\
\hline \multirow[t]{5}{*}{$\operatorname{miR}-27 a$} & Binding & 32.40 \\
\hline & Catalytic activity & 29.10 \\
\hline & $\begin{array}{l}\text { Nucleic acid binding } \\
\text { transcription }\end{array}$ & 12.10 \\
\hline & Receptor activity & 7.60 \\
\hline & Enzyme regulator activity & 7.20 \\
\hline \multirow[t]{5}{*}{ miR-34a } & Binding & 32.00 \\
\hline & Catalytic activity & 25.80 \\
\hline & $\begin{array}{l}\text { Nucleic acid binding } \\
\text { transcription }\end{array}$ & 11.40 \\
\hline & Enzyme regulator activity & 8.70 \\
\hline & Receptor activity & 8.70 \\
\hline \multirow[t]{5}{*}{$\operatorname{miR}-423-5 p$} & Binding & 34.50 \\
\hline & Catalytic activity & 25.20 \\
\hline & $\begin{array}{l}\text { Nucleic acid binding } \\
\text { transcription }\end{array}$ & 16.00 \\
\hline & Receptor activity & 6.80 \\
\hline & Transporter activity & 5.80 \\
\hline
\end{tabular}

be mediated by oncogenes including MET proto-oncogene (MET), histone deacetylase 4 (HDAC4), forkhead box P1 (FOXP1), G1/S-specific cyclin D2 (CCND2), C-X-C chemokine receptor type 4 (CXCR4) and stromal cell-derived factor 1 (SDF-1) $(25,28,31)$. Recent studies demonstrated similar tumor-suppressive function in hepatocellular 
A

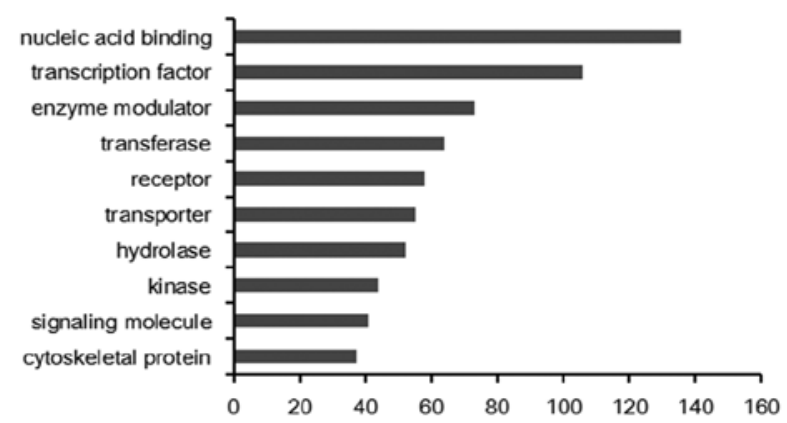

C

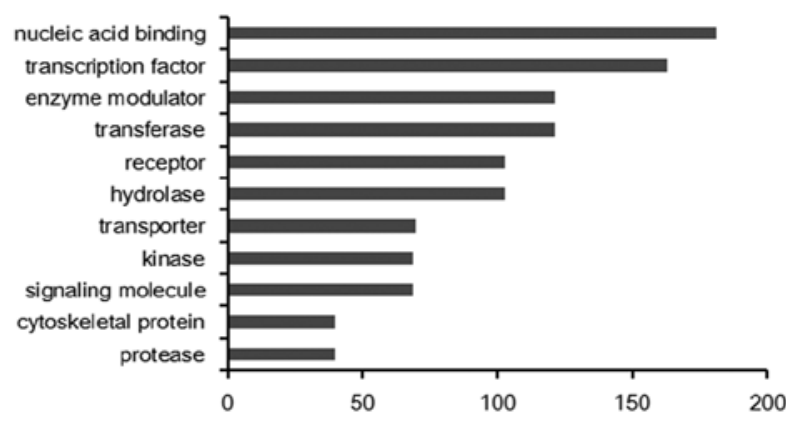

E

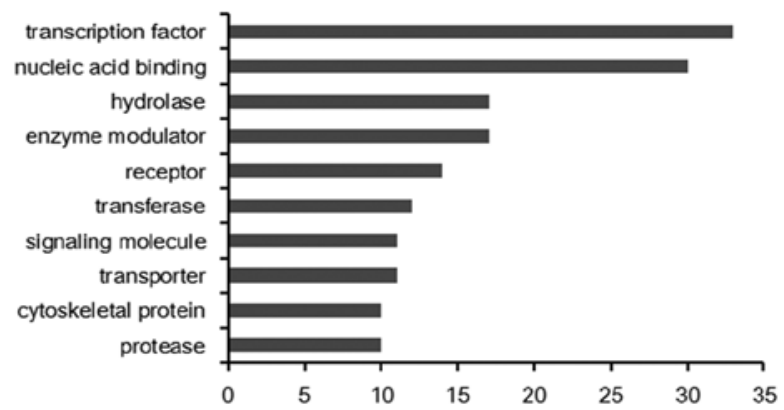

B

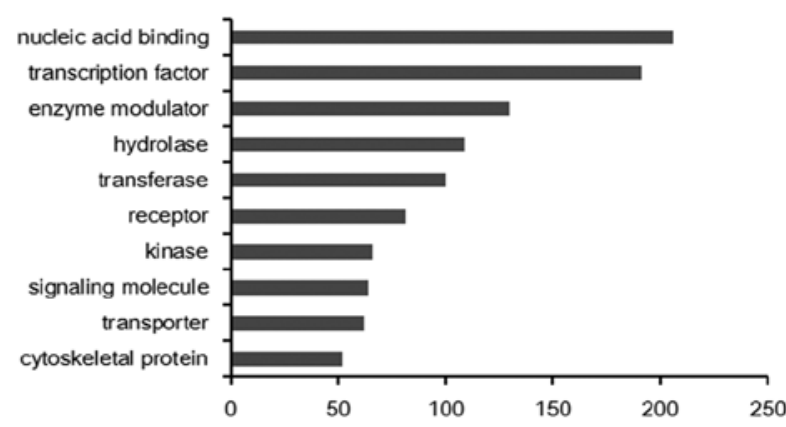

D

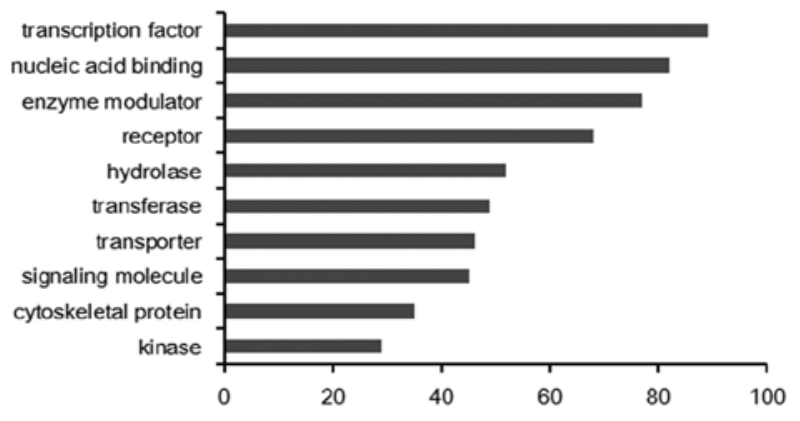

Figure 1. Major classes of GC-miRNA-related targets. (A) Classification of miR-1-related targets. (B) Major classes of miR-20a-related targets. (C) Major classes of miR-27a-related targets. (D) Major classes of miR-34a-related targets. (E) Major classes of miR-423-5p-related targets. carcinoma (HCC) by targeting endothelin-1 (ET-1) and antiapoptotic factor apoptosis inhibitor 5 (API-5) $(32,33)$. Other studies revealed that re-expression of miR-1 may be a potential therapeutic target suppressing the malignant potential of lung cancer by mesenchymal-to-epithelial transition (MET) via downregulation of Slug, a member of the snail family of transcription factors (34). Similarly, restoration of the expression and the function of miR-1 leads to oncogene-driven reduction in cell proliferation, thus making miR-1 a promising therapeutic target for a multitude of cancers.

miR-20a belongs to the miR-17-92 cluster, also known as oncomiR-1, which includes 6 microRNAs: miR-17-5p, miR-18a, miR-19a, miR-19b, miR-20a and miR-92a-16 (35). It contributes to the regulation of many types of tumors as a tumor-suppressor in oral squamous cell cancer (36) and hepatic cancer (37) or a tumor-promotor in osteosarcoma (38), bladder cancer (39), GC (40), prostate cancer (41) and cervical cancer (42). It promotes the growth, migration, and invasion of GC cells by inhibiting the early growth response 2 (EGR2) signaling pathway (40), and may be related with the malignant process of cervical cancer, particularly invasion and metastasis by targeting autophagy-related protein 7 (ATG7), tissue inhibitors of metalloproteinase 2 (TIMP2) and tankyrase 2 (TNKS2) (43). On the other hand, miR-20a is involved in the tumor inhibition of cutaneous squamous cell carcinoma (CSCC) by targeting LIM kinase-1 gene (LIK1), a metastasis promoter (44). Moreover, it targets MHC class I chain-related molecule A and B (MICA/B) to avoid NKG-mediated immune attack, thus enhancing the survival of ovarian cancer cells by immune escape (45). It has been shown that miR-20a inhibits the proliferation and metastasis of pancreatic carcinoma cells by directly downregulating Stat 3 which is related to various physiological functions (46).

Previous studies have demonstrated that miR-27a acts as an oncogenic miRNA. Its role in promoting cell proliferation, invasion and metastasis has been verified in many malignancies, such as breast cancer (47), HCC (48), nonsmall cell lung cancer (NSCLC) (49), osteosarcoma (50) and renal cancer (51). In HCC, miR-27a promotes cell proliferation through suppression of its target gene peroxisome proliferator-activated receptor $\gamma$ (PPAR- $\gamma)$ (48). Direct and indirect mechanisms by which miR-27a can regulate both MET and EGFR, thus contributing to tumor progression, was discovered in NSCLC (49). Other studies emphasize 
Table III. Pathway analysis of GC-related pathways.

\begin{tabular}{|c|c|c|}
\hline GC miRNAs & Pathway & No. of genes $(\%)$ \\
\hline \multirow[t]{8}{*}{ miR-1 } & Gonadotropin releasing hormone receptor pathway & $23(6.00)$ \\
\hline & Angiogenesis & $20(5.20)$ \\
\hline & Wnt signaling pathway & $18(4.70)$ \\
\hline & Integrin signaling pathway & $13(3.40)$ \\
\hline & EGF receptor signaling pathway & $13(3.40)$ \\
\hline & VEGF signaling pathway & $12(3.10)$ \\
\hline & PDGF signaling pathway & $12(3.10)$ \\
\hline & FGF signaling pathway & $12(3.10)$ \\
\hline \multirow[t]{6}{*}{$\operatorname{miR}-20 \mathrm{a}$} & Wnt signaling pathway & $39(7.60)$ \\
\hline & Gonadotropin releasing hormone receptor pathway & $34(6.60)$ \\
\hline & Cadherin signaling pathway & $25(4.90)$ \\
\hline & PDGF signaling pathway & $23(4.50)$ \\
\hline & Angiogenesis & $20(3.90)$ \\
\hline & Integrin signaling pathway & $19(3.70)$ \\
\hline \multirow[t]{8}{*}{$\operatorname{miR}-27 \mathrm{a}$} & Gonadotropin releasing hormone receptor pathway & $40(6.40)$ \\
\hline & Wnt signaling pathway & $27(4.30)$ \\
\hline & Angiogenesis & $23(3.70)$ \\
\hline & EGF receptor signaling pathway & $22(3.50)$ \\
\hline & Inflammation mediated by chemokine and cytokine signaling pathway & $20(3.20)$ \\
\hline & PDGF signaling pathway & $18(2.90)$ \\
\hline & Integrin signaling pathway & $18(2.90)$ \\
\hline & FGF signaling pathway & $18(2.90)$ \\
\hline \multirow[t]{7}{*}{$\operatorname{miR}-34 a$} & Gonadotropin releasing hormone receptor pathway & $19(5.80)$ \\
\hline & Angiogenesis & $14(4.30)$ \\
\hline & Inflammation mediated by chemokine and cytokine signaling pathway & $11(3.40)$ \\
\hline & Wnt signaling pathway & $10(3.10)$ \\
\hline & EGF receptor signaling pathway & $10(3.10)$ \\
\hline & TGF- $\beta$ signaling pathway & $9(2.80)$ \\
\hline & Integrin signaling pathway & $9(2.80)$ \\
\hline \multirow[t]{6}{*}{$\operatorname{miR}-423-5 p$} & Inflammation mediated by chemokine and cytokine signaling pathway & $5(6.80)$ \\
\hline & Wnt signaling pathway & $5(6.80)$ \\
\hline & Gonadotropin releasing hormone receptor pathway & $5(6.80)$ \\
\hline & Huntington disease & $3(4.10)$ \\
\hline & Heterotrimeric G-protein signaling pathway-Gi $\alpha$ and Gs $\alpha$ mediated pathway & $3(4.10)$ \\
\hline & PDGF signaling pathway & $3(4.10)$ \\
\hline
\end{tabular}

the role of miR-27a expression in sensitivity to anticancer therapies, including chemotherapy (52-58), radiotherapy (59) and thermal therapy (60). Downregulation of miR-27a is significantly associated with the expression of P-glycoprotein and multidrug resistance gene 1 (MDR1), leading to increased chemosensitivity through different targets, for example, FZD7/ $\beta$-catenin pathway (52), homeodomain-interacting protein kinase 2 (HIPK2) (54) and RUNX1 (53). Notably, miR-27 can indirectly affect chemosensitivity by acting on the tumor microenvironment through transformation of normal fibroblasts to cancer-associated fibroblasts (55). Single nucleotide polymorphism rs11671784 is in the loop of pre-miR-27a and the G/A variation can significantly decrease the expression of mature miR-27a, followed by increased RUNX-1 expres- sion and weakened chemosensitivity (53). CDC27 is a target of miR-27a by which radiosensitivity is modulated in triplenegative breast cancer (59). miR-27a may even contribute to thermal sensitivity by modulating HSP expression (60).

miR-34a is one of the earliest known tumor suppressors and is commonly downregulated in various solid cancers by targeting numerous oncogenes related to proliferation, apoptosis and invasion (61-68). miR-34a is downregulated in many cancers due to chromosomal deletion or $\mathrm{CpG}$ island methylation (69). As a direct transcriptional target of p53, decreased expression of miR-34a is partially due to mutations of p53 in several tumors (70). Ectopic expression of miR-34a can lead to cell cycle arrest, apoptosis or senescence, mimicking p53 activation (71). And miR-34a can suppress tumor metastasis 


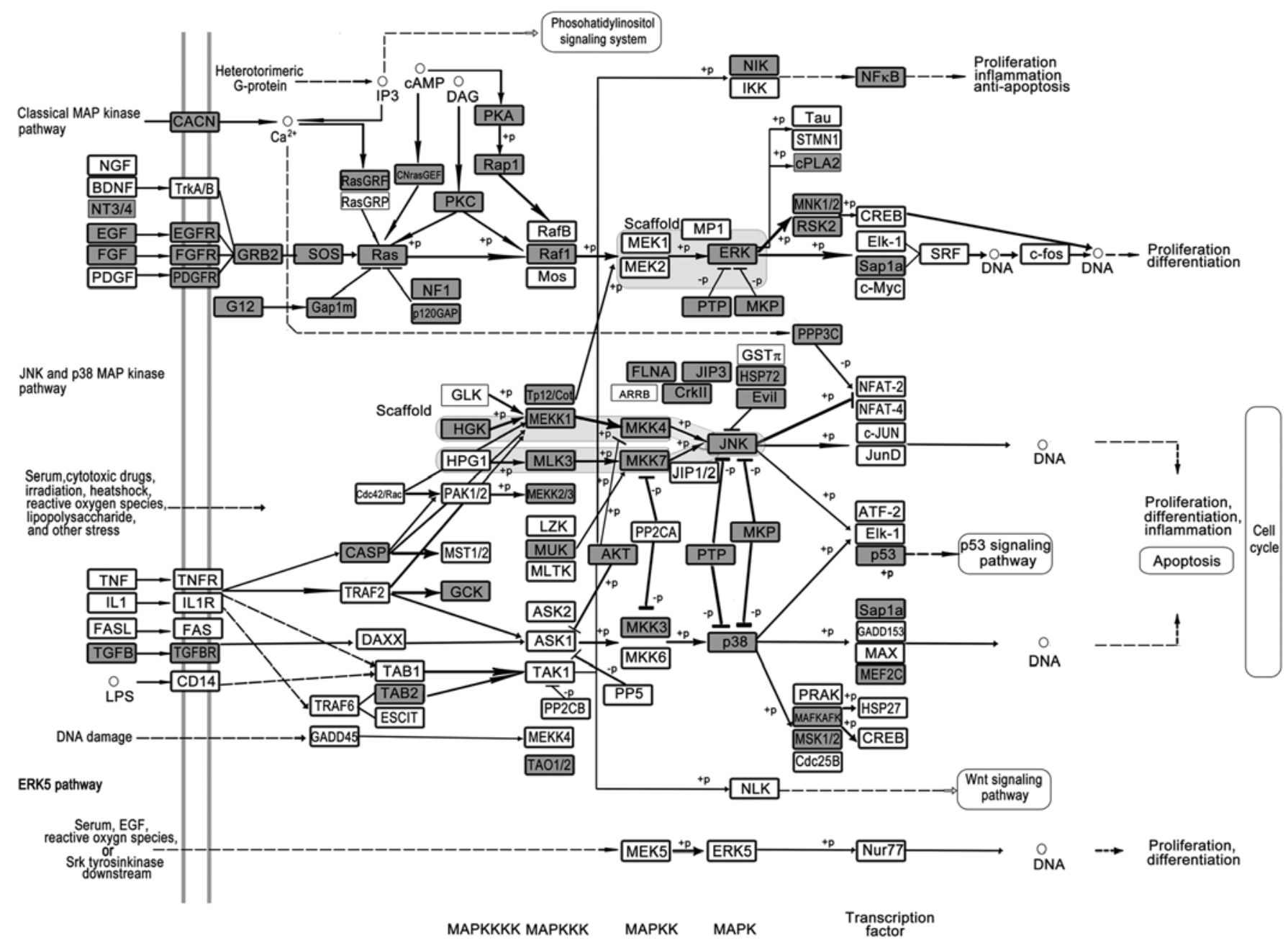

Figure 2. The MAPK signaling pathway is regulated by GC miRNAs. Grey boxes show objects that can be regulated by LC miRNAs. Solid arrows indicate activation; dashed arrows indicate indirect effect and $\perp$ indicates inhibition. Letters on lines denote the type of regulation: -p, dephosphorylation; +u, ubiquitination.

and invasion through multiple targets in a variety of signaling pathways. For example, miR-34a targets FMNL2 and E2F5, then suppresses the progression of colorectal cancer (66). In prostate cancer, miR-34a inhibits prostate cancer stem cells and metastasis by directly repressing CD44 (65). It is verified that miR-34a inhibits gastric cancer proliferation and invasion via the downregulation of MET, meanwhile it is associated with the clinicopathological features of gastric carcinoma and can be a valuable predictor of patient prognosis (67). Epithelial-mesenchymal transition (EMT) is a key step in tumor progression. miR-34a inhibits EMT by targeting Smad4 through the transforming growth factor- $\beta /$ Smad pathway in human cholangiocarcinoma (72). The role of miR-34a in regulating tumor biology has been extensively studied, while being an effective biomarker is another function of miR-34a. Serum miR-34a can be a potentially useful diagnostic biomarker of pancreatic ductal adenocarcinoma (73). Furthermore, miR-34a is likely to be involved in the treatment response of lung metastases of HCC to sorafenib (74).

The miR-423 family, identified as oncogenic miRNAs, has been explored in various types of cancers. There are two members of the miR-423 family, miR-423-3p and miR423-5p. miR-423 plays a role in promoting cell growth and regulating $\mathrm{G}(1) / \mathrm{S}$ transition by targeting $\mathrm{p} 21^{\text {Cip1/Waf1 }}$ in $\mathrm{HCC}$, however, miR-423-3p contributes to these effects, whereas miR-423-5p does not (75). Another study found that miR423-5p is involved in autophagy regulation in HCC cells (76). Regarding the target of miR-423-5p, it has been demonstrated that it regulates cell proliferation and invasion by targeting trefoil factor 1 (TFF1) in GC cells (77). The expression level of miR-423-5p is aberrant in many cancers, including GC (14), colon carcinoma (78), pancreatic cancer (79) and breast cancer (80). A five-microRNA signature identified from genome-wide serum microRNA expression profiling, including miR-423-5p, can serve as a fingerprint for GC diagnosis (14). In stage I-II colorectal cancer, serum miR423-5p was found to be significantly elevated compared with a healthy control, suggesting its value as a tool for early diagnosis (78). Furthermore, other than the diagnostic value of miR-423-5p, its role in prediction of the cancer therapeutic effect has been discovered. A classifier consisting of seven miRNAs, including overexpression of miR-423-5p, was able to identify a subgroup of glioblastoma patients who were resistant to temozolomide (81). On the contrary, the elevation of secretory miR-423-5p can be a favorable marker of the effect of sorafenib in HCC patients (76). 


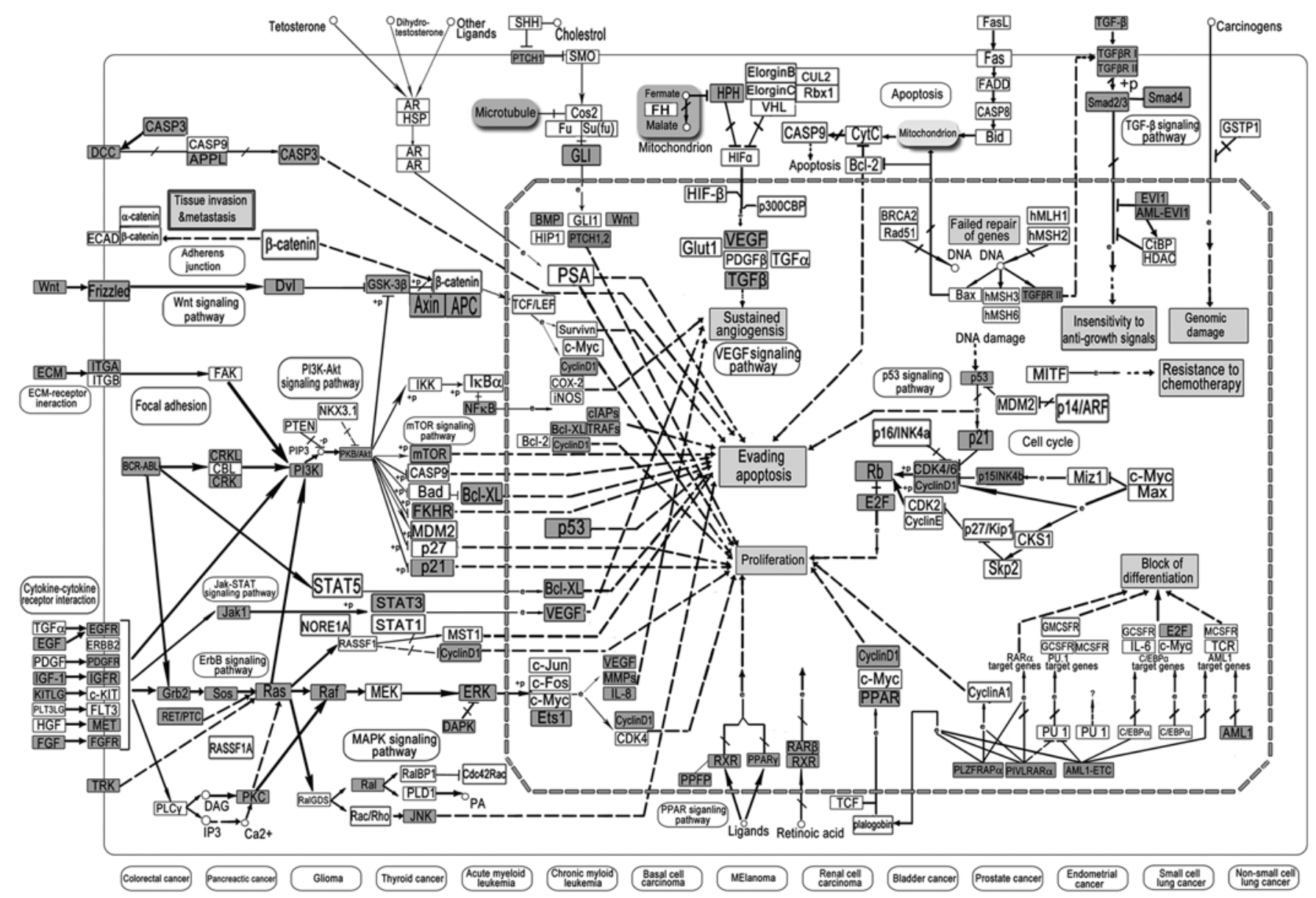

Figure 3. A schematic diagram of pathways in cancer regulated by GC miRNAs. Grey boxes show objects that can be regulated by LC miRNAs. Solid arrows indicate activation; dashed arrows indicate indirect effect and $\perp$ indicates inhibition. Letters on lines denote the type of regulation: -p, dephosphorylation; +u, ubiquitination.

Predictions and protein classification of GC-miRNA targets. A single miRNA has hundreds of potential targets in physiological and pathological conditions; therefore, investigation of miRNA-target genes provides a better description of the miRNA-involved pathways. All of the predicted targets should be analyzed to fully understand the functions of GC-related miRNAs. As shown in Table I, GC miRNAs or miRNA family has the ability to directly target between 180 and 1,218 mRNAs of genes; moreover, a unique miRNA was observed to have multiple binding sites in the 3'UTR of the mRNAs. In total, 4,032 genes are regarded as downstream targets of the 5 significant GC miRNAs. Most of the genes are potential targets of oncomirs, and these genes are most likely to be downregulated in GC cells. Among all of the predicted genes, several important regulators include: BCL3, CD69, VIP, BMP3, MAPK1, BCL9L, BCL11B, PTEN; these genes are well known to be involved in cell apoptosis, cell proliferation, cell metastasis and angiogenesis.

As shown in Fig. 1, the top 1 class of targets for miR-1, miR-20a and miR-27a includes nucleic acid binding; while the top 1 class of targets for miR-34a and miR-423-5p includes transcription factor. A total of 136 miR-1-targeting genes, 206 miR-20a-targeting genes, $181 \mathrm{miR}-27 \mathrm{a}$-targeting genes belong to the protein class of nucleic acid binding. A total of 89 miR-34a-targeting genes and 33 miR-423-5p targeting genes are in the class of transcription factor. Moreover, the class of enzyme modulator, transferase, receptor, kinase and transporter are found in the top 10 classes of all the 5 miRNArelated targets. miRNAs are likely to play a role as more refined regulators of gene expression, the minor percentage of the targets contain diverse proteins such as cytokines, transporters, hydrolases, transferases.

In agreement with our research, some groups have reported that miRNA-related oncogenes and tumor suppressors clearly show different patterns in function, expression, chromosome distribution, molecule size, free energy, targets and transcription factors (82-85).

Analysis of molecular functions, biological processes and signaling pathways for GC-miRNA-related targets. To provide a direct look at the pathways implicated in all targets of the 5 miRNAs, all the targets were used for further pathway analysis. As shown in Table II, the important molecular function and biological processes are almost identical to the potential targets of the 5 miRNAs. miR-1 contributes to the biological process of binding (34.4\%), catalytic activity (27.4\%), nucleic acid binding transcription (12\%), transporter activity (6.4\%), enzyme regulator activity (6.4\%) and receptor activity (6.4\%). miR-20a-related targets play a role in binding (35.8\%), catalytic activity (28.6\%), nucleic acid binding transcription 


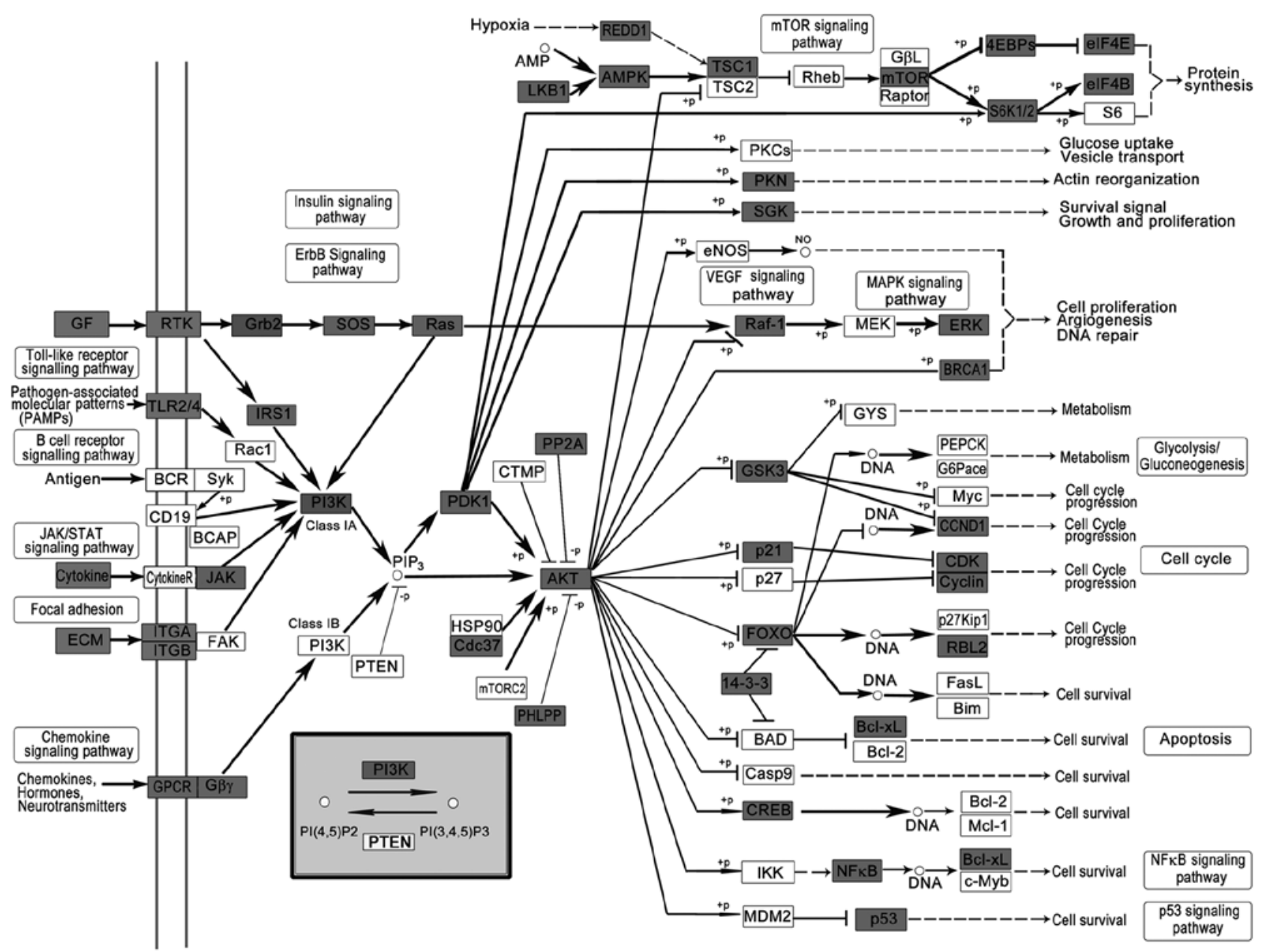

Figure 4. GC-miRNA regulation of the PI3K/Akt signaling pathway. Grey boxes show objects that can be regulated by LC miRNAs. Solid arrows indicate activation; dashed arrows indicate indirect effect and $\perp$ indicates inhibition. Letters on lines denote the type of regulation: -p, dephosphorylation.

(13.1\%), enzyme regulator activity $(6.8 \%)$ and receptor activity (5.3\%). The potential target genes of miR-27a are also involved in binding (32.4\%), catalytic activity $(29.1 \%)$, nucleic acid binding transcription (12.1\%), receptor activity (7.6\%) and enzyme regulator activity (7.2\%). The miR-34a-related genes are expected to contribute to binding, catalytic activity, nucleic acid binding transcription, enzyme regulator activity and receptor activity. Furthermore, the target genes of miR-423-5p participate in binding (34.5\%), catalytic activity (25.2\%), nucleic acid binding transcription (16\%), receptor activity (6.8\%) and transporter activity (Table II).

The potential target genes of each miRNA were classified into several main groups, and the top 10 classes are respectively shown in Table III. miR-1, miR-27a, miR-34a and $\mathrm{miR}-423-5 \mathrm{p}$ are found to participate in the gonadotropin release hormone receptor pathway; miR-1, miR-20a, miR-27a and miR-34a are involved in the pathway of angiogenesis; miR-1, miR-27a and miR-423-5p are involved in Wnt signaling pathway (Table III). As predicted, miR-1 contributes to the pathways of EGF receptor signaling, VEGF signaling, PDGF signaling and FGF signaling, thus, the dysregulation of miR-1 is believed to play the most important role in the tumorigenesis in gastric cancer.
Pathway mapping of GC-miRNA-related targets. To give a direct view of the GC miRNA-related genes, all of the targets of miR-1, miR-20a, miR-27a, miR-34a and miR-423-5p were used for further pathway analysis. The 5 most important pathways include the MAPK signaling pathway (Fig. 2), PI3K-Akt signaling pathway (Fig. 3), pathways in cancer (Fig. 4), HTLV-I infection (Fig. 5) and the Ras signaling pathway (Fig. 6). These pathways are well known to play important roles in cell growth, cell metastasis, cell invasion and intercellular communication in various types of cancer (86-92).

As is shown is Fig. 2, the mitogen-activated protein kinase (MAPK) signaling pathway mainly affects the biological process of cell proliferation, differentiation, inflammation and the cell cycle. The MAPK signaling pathway is also associated with the p53 signaling and Wnt signaling pathways, two pathways that are known to determine tumorigenesis (Fig. 2). MAPK signaling is accurately regulated so that optimal biological activities are achieved and health is maintained; however, activation of the MAPK pathway is a frequent event in human cancer and is often the result of activating mutations in the BRAF and RAS oncogenes (93). Members of the MAP kinase family are evolutionarily conserved regulators that mediate signal transduction and play essential roles in various 


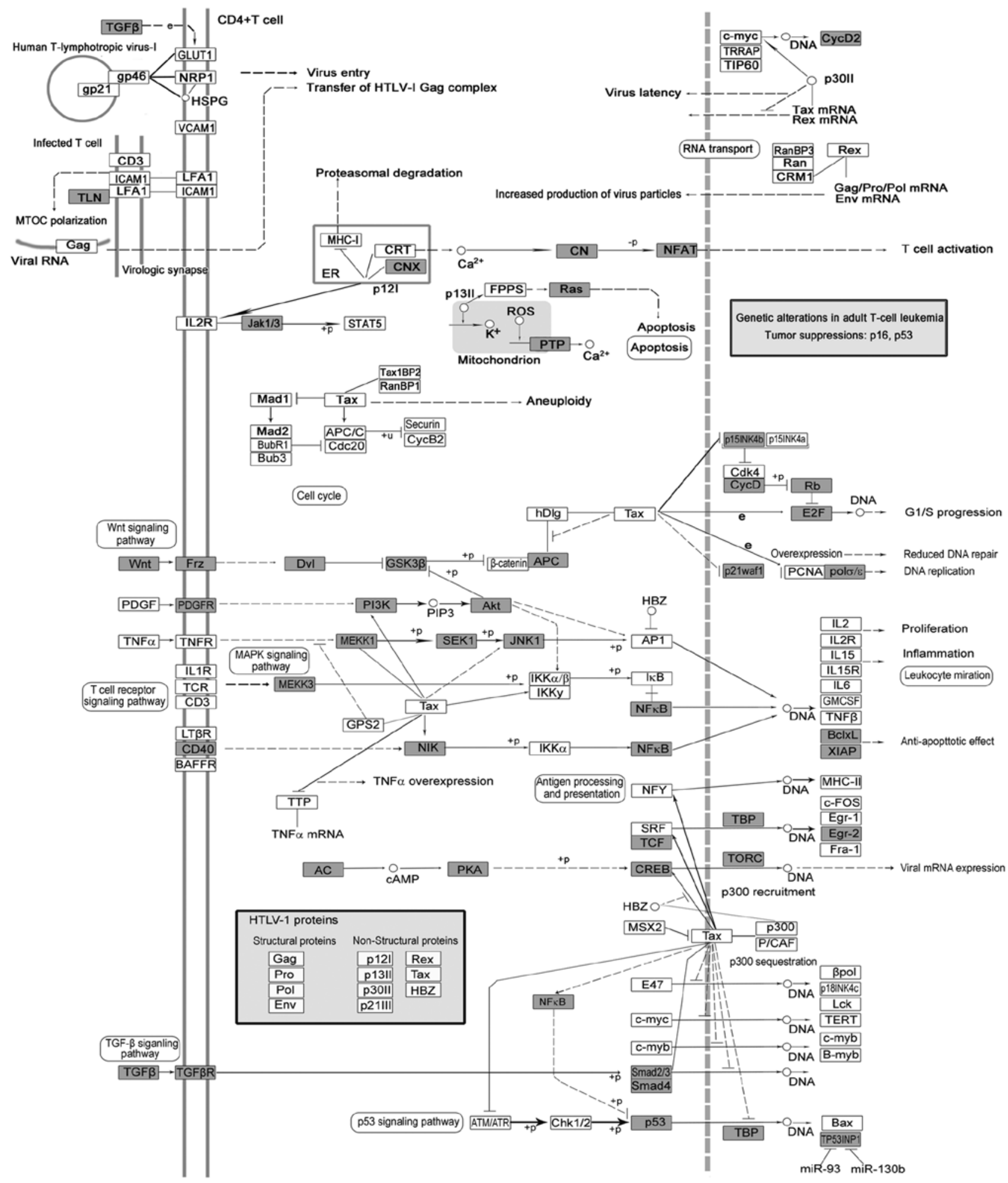

Figure 5. Regulation of the HTLV-1 pathway by GC miRNAs. Grey boxes show objects that can be regulated by LC miRNAs. Solid arrows indicate activation; dashed arrows indicate indirect effect and $\perp$ indicates inhibition. Letters on lines denote the type of regulation: -p, dephosphorylation; +u, ubiquitination.

physiological processes. Previous studies in mouse models have demonstrated that MAPK controls cancer development, and these models are expected to provide novel strategies for cancer therapy (94). Although miR-155, miR-200 and miR-141 have been reported to regulate the expression of MAPK-related genes $(95,96)$, the miRNA-MAPK pathway still needs further exploration.
Pathways in cancer are more closely linked with tumorigenesis, and include the MAPK, PI3K-Akt, VEGF, p53, PPAR and TGF- $\beta$ signaling pathways (Fig. 3). As shown in Fig. 3, the pathways in cancer have demonstrated the acquisition of biological capabilities such as blockade of differentiation, resistance to apoptosis, unlimited replicative potential, sustained angiogenesis, tissue invasion and 


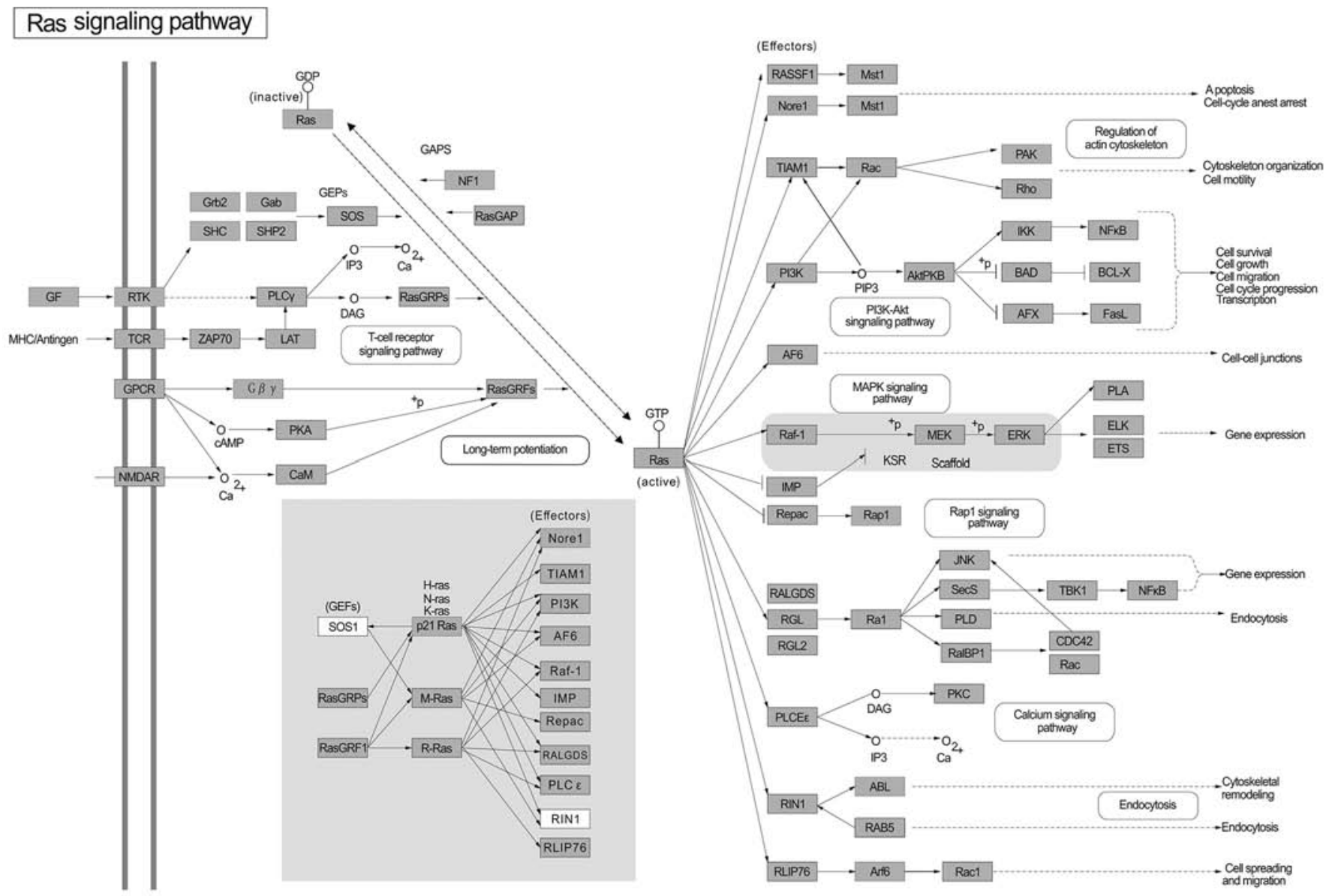

Figure 6. Analysis of the Ras signaling pathway regulated by GC miRNAs. Grey boxes show objects that can be regulated by LC miRNAs. Solid arrows indicate activation; dashed arrows indicate indirect effect and $\perp$ indicates inhibition. Letters on lines denote the type of regulation: $-\mathrm{p}$, dephosphorylation; + $\mathrm{u}$, ubiquitination.

metastasis for the transformation of normal cells into highly malignant tumor cells. The important GC-miRNA-related genes are Wnt, STAT3, p21, p53, BCL-2, FAS and TGF- $\beta$; however, more common abnormalities in oncogenes and tumor-suppressor genes regulated by GC miRNAs can be used as potential therapeutic targets (Fig. 3).

The phosphatidylinositol-3-kinase (PI3K)-Akt signaling pathway (Fig. 4) has been reported to show frequent change in human cancer, and is thought to specifically interact with EGFR/ERBB family receptors (97-99). It is reported that the PI3K-Akt signaling pathway mediates regulation of p27, and is associated with cell cycle arrest and apoptosis in cervical cancer (100). In addition, the PI3K/Akt/mTOR pathway is also regarded as a therapeutic target in ovarian cancer (101). In bone cancer, cancer pain is closely linked with MCP-1 which stimulates spinal microglia, mediated by the PI3K/Akt pathway (102). In human prostate cancer, CD147 is reported to modulate autophagy though the PI3K/Akt/mTOR pathway in PC-3 cells (103). More inhibitors are designed to target the PI3K/Akt/mTOR pathway in clinical trials (104-107). In summary, numerous members of the PI3K/Akt pathway are crucial to many aspects of cell growth and survival, and are altered by amplification, mutation and translocation frequently, with resultant activation of the pathway.
Human T cell leukemia virus 1 (HTLV-1) is a retrovirus that causes adult T cell leukemia (ATL) and neurological disorder, the tropical spastic paraparesis (HAM/TSP) (Fig. 5). The pathogenesis apparently results from the pleiotropic function of Tax protein, which is a key regulator of viral replication (Fig. 5). Tax encoded by HTLV-1 has been implicated in tumorigenesis, and is involved in the dysregulation of anti-apoptosis and cell proliferation (108). Recently, miR-28-3p has been reported to be a cellular restriction factor that inhibits HTLV-1 replication and infection (109). However, the role of miRNA and HTLV-1 in cancer, particularly in GC, remains unclear.

Ras is another well-known regulator that activates many signaling cascades (Fig. 6); Ras genes encode proteins that are activated in an intracellular signaling network controling differentiation, proliferation and cell survival (110-112). Ras mutations are common in human malignancies, especially in cancer, and have been identified in $>30 \%$ of human cancers. Ras and the downstream proteins, Raf and MEK, play an important role in the development of malignancies, and often show frequent expression in cancers. Therefore, a variety of agents are designed to disrupt signaling though Ras or the downstream proteins (113).

In the present study, we constructed a detailed biological frame by in-depth analysis of the complex network comprising 
GC-miRNA-related targets. These results are believed to provide a better understanding of the miRNA-regulated pathways in gastric cancer and identify novel potential targets for future clinical use.

\section{Acknowledgements}

The present study was supported by grants from the National Natural Science Foundation of China (nos. 81201946 and 81372394) and the National Research Platform of Clinical Evaluation Technology for New Anticancer Drugs (no. 2013ZX09303001). This study was also supported by the Chinese Ministry of Education Research Fund for doctoral programs (no. 2012202120013), Tianjin City High School Science and Technology Fund Planning Project (no. 20130122) and Science Foundation of Medical University Of Tianjin (no. 2011KY15).

\section{References}

1. Fernández-Fernández FJ and Sesma P: Gastric cancer. Lancet 374: 1594, author reply 1594-1595, 2009.

2. Hartgrink HH, Jansen EP, van Grieken NC and van de Velde CJ: Gastric cancer. Lancet 374: 477-490, 2009.

3. Yamaoka Y, Kato M and Asaka M: Geographic differences in gastric cancer incidence can be explained by differences between Helicobacter pylori strains. Intern Med 47: 1077-1083, 2008.

4. Tsugane S and Sasazuki S: Diet and the risk of gastric cancer: Review of epidemiological evidence. Gastric Cancer 10: 75-83, 2007.

5. Bae JM, Lee EJ and Guyatt G: Citrus fruit intake and stomach cancer risk: A quantitative systematic review. Gastric Cancer 11: 23-32, 2008

6. He L and Hannon GJ: MicroRNAs: Small RNAs with a big role in gene regulation. Nat Rev Genet 5: 522-531, 2004.

7. Bartel DP: MicroRNAs: Genomics, biogenesis, mechanism, and function. Cell 131: 11-29, 2007.

8. Bartel DP: MicroRNAs: Genomics, biogenesis, mechanism, and function. Cell 116: 281-297, 2004.

9. Koturbash I, Zemp FJ, Pogribny I and Kovalchuk O: Small molecules with big effects: The role of the microRNAome in cancer and carcinogenesis. Mutat Res 722: 94-105, 2011.

10. Peláez $\mathrm{N}$ and Carthew RW: Biological robustness and the role of microRNAs: A network perspective. Curr Top Dev Biol 99 237-255, 2012.

11. Zhang H, Yang H, Zhang C, Jing Y, Wang C, Liu C, Zhang R, Wang J, Zhang J, Zen K, et al: Investigation of microRNA expression in human serum during the aging process. J Gerontol A Biol Sci Med Sci 70: 102-109, 2015.

12. Calin GA, Sevignani C, Dumitru CD, Hyslop T, Noch E, Yendamuri S, Shimizu M, Rattan S, Bullrich F, Negrini M, et al: Human microRNA genes are frequently located at fragile sites and genomic regions involved in cancers. Proc Natl Acad Sci USA 101: 2999-3004, 2004.

13. Liu R, Chen X, Du Y, Yao W, Shen L, Wang C, Hu Z, Zhuang R, Ning G, Zhang C, et al: Serum microRNA expression profile as a biomarker in the diagnosis and prognosis of pancreatic cancer. Clin Chem 58: 610-618, 2012.

14. Liu R, Zhang C, Hu Z, Li G, Wang C, Yang C, Huang D, Chen X, Zhang $\mathrm{H}$, Zhuang $\mathrm{R}$, et al: A five-microRNA signature identified from genome-wide serum microRNA expression profiling serves as a fingerprint for gastric cancer diagnosis. Eur J Cancer 47: 784-791, 2011

15. Wang C, Hu J, Lu M, Gu H, Zhou X, Chen X, Zen K, Zhang CY, Zhang T, Ge J, et al: A panel of five serum miRNAs as a potential diagnostic tool for early-stage renal cell carcinoma. Sci Rep 5 7610,2015

16. Luo Y, Wang C, Chen X, Zhong T, Cai X, Chen S, Shi Y, Hu J, Guan X, Xia Z, et al: Increased serum and urinary microRNAs in children with idiopathic nephrotic syndrome. Clin Chem 59: 658-666, 2013.

17. Esquela-Kerscher A and Slack FJ: Oncomirs - microRNAs with a role in cancer. Nat Rev Cancer 6: 259-269, 2006.
18. Loscalzo J, Kohane I and Barabasi AL: Human disease classification in the postgenomic era: A complex systems approach to human pathobiology. Mol Syst Biol 3: 124, 2007.

19. Taneja SS, Goddy G, Kibel AS, Penson DF and Wei JT: Prostate cancer detection using a novel computerized three-dimensional prostate biopsy template (Targetscan (Tm)): Results of a multicenter prospective data registry. J Urol 181: 712-712, 2009.

20. Mi H and Thomas P: PANTHER pathway: An ontology-based pathway database coupled with data analysis tools. Methods Mol Biol 563: 123-140, 2009.

21. Mi H, Guo N, Kejariwal A and Thomas PD: PANTHER version 6: Protein sequence and function evolution data with expanded representation of biological pathways. Nucleic Acids Res 35: D247-D252, 2007.

22. Huang DW, Sherman BT, Tan Q, Collins JR, Alvord WG, Roayaei J, Stephens R, Baseler MW, Lane HC and Lempicki RA: The DAVID Gene Functional Classification Tool: A novel biological module-centric algorithm to functionally analyze large gene lists. Genome Biol 8: R183, 2007.

23. Kanehisa M, Araki M, Goto S, Hattori M, Hirakawa M, Itoh M, Katayama T, Kawashima S, Okuda S, Tokimatsu T, et al: KEGG for linking genomes to life and the environment. Nucleic Acids Res 36: D480-D484, 2008.

24. Han C, Yu Z, Duan Z and Kan Q: Role of microRNA-1 in human cancer and its therapeutic potentials. Biomed Res Int 2014: 428371, 2014

25. Nohata N, Hanazawa T, Enokida H and Seki N: microRNA-1/133a and microRNA-206/133b clusters: Dysregulation and functional roles in human cancers. Oncotarget 3: 9-21, 2012.

26. Liu YN, Yin JJ, Abou-Kheir W, Hynes PG, Casey OM, Fang L, Yi M, Stephens RM, Seng V, Sheppard-Tillman H, et al: miR-1 and miR-200 inhibit EMT via Slug-dependent and tumorigenesis via Slug-independent mechanisms. Oncogene 32: 296-306, 2013.

27. Reid JF, Sokolova V, Zoni E, Lampis A, Pizzamiglio S, Bertan C, Zanutto S, Perrone F, Camerini T, Gallino G, et al: miRNA profiling in colorectal cancer highlights miR-1 involvement in MET-dependent proliferation. Mol Cancer Res 10: 504-515, 2012.

28. Yan D, Dong XE, Chen X, Wang L, Lu C, Wang J, Qu J and Tu L: MicroRNA-1/206 targets c-Met and inhibits rhabdomyosarcoma development. J Biol Chem 284: 29596-29604, 2009.

29. Nasser MW, Datta J, Nuovo G, Kutay H, Motiwala T, Majumder S, Wang B, Suster S, Jacob ST and Ghoshal K: Down-regulation of micro-RNA-1 (miR-1) in lung cancer. Suppression of tumorigenic property of lung cancer cells and their sensitization to doxorubicin-induced apoptosis by miR-1. J Biol Chem 283 : 33394-33405, 2008.

30. Wang F, Song G, Liu M, Li X and Tang H: miRNA-1 targets fibronectinl and suppresses the migration and invasion of the HEp2 laryngeal squamous carcinoma cell line. FEBS Lett 585: 3263-3269, 2011

31. Leone V, D'Angelo D, Rubio I, de Freitas PM, Federico A, Colamaio M, Pallante P, Medeiros-Neto G and Fusco A: miR-1 is a tumor suppressor in thyroid carcinogenesis targeting CCND2, CXCR4, and SDF-1alpha. J Clin Endocrinol Metab 96: E1388-E1398, 2011.

32. Li D, Liu Y, Li H, Peng JJ, Tan Y, Zou Q, Song XF, Du M, Yang ZH, Tan Y, et al: MicroRNA-1 promotes apoptosis of hepatocarcinoma cells by targeting apoptosis inhibitor-5 (API-5). FEBS Lett 589: 68-76, 2015.

33. Li D, Yang P, Li H, Cheng P, Zhang L, Wei D, Su X, Peng J, Gao H, Tan Y, et al: MicroRNA-1 inhibits proliferation of hepatocarcinoma cells by targeting endothelin-1. Life Sci 91: 440-447, 2012.

34. Tominaga E, Yuasa K, Shimazaki S and Hijikata T: MicroRNA-1 targets Slug and endows lung cancer A549 cells with epithelial and anti-tumorigenic properties. Exp Cell Res 319: 77-88, 2013.

35. Jung YJ, Kim JW, Park SJ, Min BY, Jang ES, Kim NY, Jeong SH, Shin CM, Lee SH, Park YS, et al: c-Myc-mediated overexpression of miR-17-92 suppresses replication of hepatitis B virus in human hepatoma cells. J Med Virol 85: 969-978, 2013.

36. Chang CC, Yang YJ, Li YJ, Chen ST, Lin BR, Wu TS, Lin SK, Kuo MY and Tan CT: MicroRNA-17/20a functions to inhibit cell migration and can be used a prognostic marker in oral squamous cell carcinoma. Oral Oncol 49: 923-931, 2013.

37. Fan MQ, Huang CB, Gu Y, Xiao Y, Sheng JX and Zhong L: Decrease expression of microRNA-20a promotes cancer cell proliferation and predicts poor survival of hepatocellular carcinoma. J Exp Clin Cancer Res 32: 21, 2013.

38. No authors listed: miR-20a facilitates metastasis of osteosarcoma cells to lung tissue. Bonekey Rep 1: 76, 2012. 
39. Yoshino $\mathrm{H}$, Seki N, Itesako T, Chiyomaru T, Nakagawa $\mathrm{M}$ and Enokida H: Aberrant expression of microRNAs in bladder cancer. Nat Rev Urol 10: 396-404, 2013.

40. Li X, Zhang Z, Yu M, Li L, Du G, Xiao W and Yang H: Involvement of miR-20a in promoting gastric cancer progression by targeting early growth response 2 (EGR2). Int J Mol Sci 14: 16226-16239, 2013.

41. Li X, Pan JH, Song B, Xiong EQ, Chen ZW, Zhou ZS and Su YP: Suppression of CX43 expression by miR-20a in the progression of human prostate cancer. Cancer Biol Ther 13: 890-898, 2012.

42. Zhao S, Yao DS, Chen JY and Ding N: Aberrant expression of miR-20a and miR-203 in cervical cancer. Asian Pac J Cancer Prev 14: 2289-2293, 2013

43. Zhao S, Yao D, Chen J, Ding N and Ren F: miR-20a promotes cervical cancer proliferation and metastasis in vitro and in vivo. PLoS One 10: e0120905, 2015.

44. Zhou J, Liu R, Luo C, Zhou X, Xia K, Chen X, Zhou M, Zou Q, Cao P and Cao K: miR-20a inhibits cutaneous squamous cell carcinoma metastasis and proliferation by directly targeting LIMK1. Cancer Biol Ther 15: 1340-1349, 2014.

45. Xie J, Liu M, Li Y, Nie Y, Mi Q and Zhao S: Ovarian tumor-associated microRNA-20a decreases natural killer cell cytotoxicity by downregulating MICA/B expression. Cell Mol Immunol 11: 495-502, 2014

46. Yan H, Wu J, Liu W, Zuo Y, Chen S, Zhang S, Zeng M and Huang W: MicroRNA-20a overexpression inhibited proliferation and metastasis of pancreatic carcinoma cells. Hum Gene Ther 21: 1723-1734, 2010

47. Guttilla IK and White BA: Coordinate regulation of FOXO1 by miR-27a, miR-96, and miR-182 in breast cancer cells. J Biol Chem 284: 23204-23216, 2009.

48. Li S, Li J, Fei BY, Shao D, Pan Y, Mo ZH, Sun BZ, Zhang D, Zheng X, Zhang M, et al: miR-27a promotes hepatocellular carcinoma cell proliferation through suppression of its target gene peroxisome proliferator-activated receptor $\gamma$. Chin Med J (Engl) 128: 941-947, 2015.

49. Acunzo M, Romano G, Palmieri D, Laganá A, Garofalo M, Balatti V, Drusco A, Chiariello M, Nana-Sinkam P and Croce CM: Cross-talk between MET and EGFR in non-small cell lung cancer involves miR-27a and Sprouty2. Proc Natl Acad Sci USA 110: 8573-8578, 2013.

50. Salah Z, Arafeh R, Maximov V, Galasso M, Khawaled S, Abou-Sharieha S, Volinia S, Jones KB, Croce CM and Aqeilan RI: miR-27a and miR-27a* contribute to metastatic properties of osteosarcoma cells. Oncotarget 6: 4920-4935, 2015

51. Peng H, Wang X, Zhang P, Sun T, Ren X and Xia Z: miR-27a promotes cell proliferation and metastasis in renal cell carcinoma. Int J Clin Exp Pathol 8: 2259-2266, 2015.

52. Chen Z, Ma T, Huang C, Zhang L, Lv X, Xu T, Hu T and Li J: miR-27a modulates the MDR1/P-glycoprotein expression by inhibiting FZD7/ $\beta$-catenin pathway in hepatocellular carcinoma cells. Cell Signal 25: 2693-2701, 2013.

53. Deng Y, Bai H and Hu H: rs11671784 G/A variation in miR-27a decreases chemo-sensitivity of bladder cancer by decreasing miR-27a and increasing the target RUNX-1 expression. Biochem Biophys Res Commun 458: 321-327, 2015.

54. Li Z, Hu S, Wang J, Cai J, Xiao L, Yu L and Wang Z: miR-27a modulates MDR1/P-glycoprotein expression by targeting HIPK2 in human ovarian cancer cells. Gynecol Oncol 119: 125-130, 2010.

55. Tanaka K, Miyata H, Sugimura K, Fukuda S, Kanemura T, Yamashita K, Miyazaki Y, Takahashi T, Kurokawa Y, Yamasaki M, et al: miR-27 is associated with chemoresistance in esophageal cancer through transformation of normal fibroblasts to cancer-associated fibroblasts. Carcinogenesis 36: 894-903, 2015.

56. Zhang H, Li M, Han Y, Hong L, Gong T, Sun L and Zheng X: Down-regulation of miR-27a might reverse multidrug resistance of esophageal squamous cell carcinoma. Dig Dis Sci 55 2545-2551, 2010

57. Zhao X, Yang L and Hu J: Down-regulation of miR-27a might inhibit proliferation and drug resistance of gastric cancer cells. J Exp Clin Cancer Res 30: 55, 2011

58. Zhu H, Wu H, Liu X, Evans BR, Medina DJ, Liu CG and Yang JM: Role of microRNA miR-27a and miR-451 in the regulation of MDR1/P-glycoprotein expression in human cancer cells. Biochem Pharmacol 76: 582-588, 2008.

59. Ren YQ, Fu F and Han J: miR-27a modulates radiosensitivity of triple-negative breast cancer (TNBC) cells by targeting CDC27. Med Sci Monit 21: 1297-1303, 2015
60. Kariya A, Furusawa Y, Yunoki T, Kondo T and Tabuchi Y: A microRNA-27a mimic sensitizes human oral squamous cell carcinoma HSC-4 cells to hyperthermia through downregulation of Hsp110 and Hsp90. Int J Mol Med 34: 334-340, 2014.

61. Coutinho-Camillo CM, Lourenço SV, de Araújo Lima L, Kowalski LP and Soares FA: Expression of apoptosis-regulating miRNAs and target mRNAs in oral squamous cell carcinoma. Cancer Genet 208: 382-389, 2015.

62. Hong JH, Roh KS, Suh SS, Lee S, Sung SW, Park JK, Byun JH and Kang JH: The expression of microRNA-34a is inversely correlated with c-MET and CDK6 and has a prognostic significance in lung adenocarcinoma patients. Tumour Biol: Jun 25 , 2015 (Epub ahead of print). http://dx.doi.org/10.1007/s13277015-3428-9.

63. Isosaka M, Niinuma T, Nojima M, Kai M, Yamamoto E, Maruyama R, Nobuoka T, Nishida T, Kanda T, Taguchi T, et al: A screen for epigenetically silenced microRNA genes in gastrointestinal stromal tumors. PLoS One 10: e0133754, 2015.

64. Lin L, Jiang H, Huang M, Hou X, Sun X, Jiang X, Dong X, Sun X, Zhou B and Qiao H: Depletion of histone deacetylase 1 inhibits metastatic abilities of gastric cancer cells by regulating the miR-34a/CD44 pathway. Oncol Rep 34: 663-672, 2015.

65. Liu C, Kelnar K, Liu B, Chen X, Calhoun-Davis T, Li H, Patrawala L, Yan H, Jeter C, Honorio S, et al: The microRNA miR-34a inhibits prostate cancer stem cells and metastasis by directly repressing CD44. Nat Med 17: 211-215, 2011.

66. Lu G, Sun Y, An S, Xin S, Ren X, Zhang D, Wu P, Liao W, Ding Y and Liang L: MicroRNA-34a targets FMNL2 and E2F5 and suppresses the progression of colorectal cancer. Exp Mol Pathol 99: 173-179, 2015.

67. Wei B, Huang QY, Huang SR, Mai W and Zhong XG: MicroRNA 34a attenuates the proliferation, invasion and metastasis of gastric cancer cells via downregulation of MET. Mol Med Rep 12: 5255-5261, 2015.

68. Yu L, Xiong J, Guo L, Miao L, Liu S and Guo F: The effects of lanthanum chloride on proliferation and apoptosis of cervical cancer cells: Involvement of let-7a and miR-34a microRNAs. Biometals 28: 879-890, 2015.

69. Hermeking H: The miR-34 family in cancer and apoptosis. Cell Death Differ 17: 193-199, 2010.

70. Kasinski AL and Slack FJ: miRNA-34 prevents cancer initiation and progression in a therapeutically resistant K-ras and p53-induced mouse model of lung adenocarcinoma. Cancer Res 72: 5576-5587, 2012.

71. He L, He X, Lowe SW and Hannon GJ: microRNAs join the p53 network - another piece in the tumour-suppression puzzle. Nat Rev Cancer 7: 819-822, 2007.

72. Qiao P, Li G, Bi W, Yang L, Yao L and Wu D: microRNA-34a inhibits epithelial mesenchymal transition in human cholangiocarcinoma by targeting Smad4 through transforming growth factor-beta/Smad pathway. BMC Cancer 15: 469, 2015.

73. Alemar B, Izetti P, Gregório C, Macedo GS, Castro MA, Osvaldt AB, Matte U and Ashton-Prolla P: miRNA-21 and miRNA-34a are potential minimally invasive biomarkers for the diagnosis of pancreatic ductal adenocarcinoma. Pancreas: Aug 10,2015 (Epub ahead of print).

74. Shi Y and Huang A: Effects of sorafenib on lung metastasis in rats with hepatocellular carcinoma: The role of microRNAs. Tumour Biol: May 31, 2015 (Epub ahead of print). http://dx.doi. org/10.1007/s13277-015-3565-1.

75. Lin J, Huang S, Wu S, Ding J, Zhao Y, Liang L, Tian Q, Zha R, Zhan R and He X: MicroRNA-423 promotes cell growth and regulates $\mathrm{G}(1) / \mathrm{S}$ transition by targeting $\mathrm{p} 21 \mathrm{Cip} 1 / \mathrm{Waf} 1$ in hepatocellular carcinoma. Carcinogenesis 32: 1641-1647, 2011.

76. Stiuso P, Potenza N, Lombardi A, Ferrandino I, Monaco A, Zappavigna S, Vanacore D, Mosca N, Castiello F, Porto S, et al: MicroRNA-423-5p promotes autophagy in cancer cells and is increased in serum from hepatocarcinoma patients treated with sorafenib. Mol Ther Nucleic Acids 4: e233, 2015.

77. Liu J, Wang X, Yang X, Liu Y, Shi Y, Ren J and Guleng B: miRNA423-5p regulates cell proliferation and invasion by targeting trefoil factor 1 in gastric cancer cells. Cancer Lett 347: 98-104, 2014

78. $\mathrm{Lu} \mathrm{X}$ and $\mathrm{Lu} \mathrm{J}$ : The significance of detection of serum miR-423-5p and miR-484 for diagnosis of colorectal cancer. Clin Lab 61: 187-190, 2015.

79. Ali S, Saleh H, Sethi S, Sarkar FH and Philip PA: MicroRNA profiling of diagnostic needle aspirates from patients with pancreatic cancer. Br J Cancer 107: 1354-1360, 2012. 
80. Zhao H, Gao A, Zhang Z, Tian R, Luo A, Li M, Zhao D, Fu L, Fu L, Dong JT, et al: Genetic analysis and preliminary function study of miR-423 in breast cancer. Tumour Biol 36: 4763-4771, 2015.

81. Yan W, Liu Y, Yang P, Wang Z, You Y and Jiang T: MicroRNA profiling of Chinese primary glioblastoma reveals a temozolomide-chemoresistant subtype. Oncotarget 6: 11676-11682, 2015.

82. Wang D, Qiu C, Zhang H, Wang J, Cui Q and Yin Y: Human microRNA oncogenes and tumor suppressors show significantly different biological patterns: From functions to targets. PLoS One 5: e13067, 2010.

83. Lv H, Pei J, Liu H, Wang H and Liu J: A polymorphism site in the pre-miR-34a coding region reduces miR-34a expression and promotes osteosarcoma cell proliferation and migration. Mol Med Rep 10: 2912-2916, 2014.

84. Kisseljov FL: MicroRNAs and cancer. Mol Biol 48: 197-206, 2014.

85. Tutar L, Tutar E and Tutar Y: MicroRNAs and cancer; an overview. Curr Pharm Biotechnol 15: 430-437, 2014

86. Li Y, Che Q, Bian Y, Zhou Q, Jiang F, Tong H, Ke J, Wang K and Wan XP: Autocrine motility factor promotes epithelial-mesenchymal transition in endometrial cancer via MAPK signaling pathway. Int J Oncol 47: 1017-1024, 2015.

87.Zhao L, Wang Y, Yan Q, Lv W, Zhang Y and He S: Exogenous hydrogen sulfide exhibits anti-cancer effects though p38 MAPK signaling pathway in C6 glioma cells. Biol Chem 396: 1247-1253, 2015.

88. Yan H, Xin S, Wang H, Ma J, Zhang $\mathrm{H}$ and Wei H: Baicalein inhibits MMP-2 expression in human ovarian cancer cells by suppressing the p38 MAPK-dependent NF- $\kappa$ B signaling pathway. Anticancer Drugs 26: 649-656, 2015.

89. Nakareangrit W, Thiantanawat A, Visitnonthachai D, Watcharasit P and Satayavivad J: Sodium arsenite inhibited genomic estrogen signaling but induced $p E R \alpha$ (Ser118) via MAPK pathway in breast cancer cells. Environ Toxicol: Mar 2, 2015 (Epub ahead of print). doi: 10.1002/tox.22122.

90. Chang L, Graham PH, Ni J, Hao J, Bucci J, Cozzi PJ and Li Y: Targeting PI3K/Akt/mTOR signaling pathway in the treatment of prostate cancer radioresistance. Crit Rev Oncol Hematol: Jul 18, 2015 (Epub ahead of print). doi: 10.1016/j. critrevonc.2015.07.005

91.Xia P and Xu XY: PI3K/Akt/mTOR signaling pathway in cancer stem cells: From basic research to clinical application. Am J Cancer Res 5: 1602-1609, 2015.

92. Wang L, Wu J, Lu J, Ma R, Sun D and Tang J: Regulation of the cell cycle and PI3K/Akt/mTOR signaling pathway by tanshinone I in human breast cancer cell lines. Mol Med Rep 11: 931-939, 2015.

93.Zuidervaart W, van Nieuwpoort F, Stark M, Dijkman R, Packer L, Borgstein AM, Pavey S, van der Velden P, Out C, Jager MJ, et al: Activation of the MAPK pathway is a common event in uveal melanomas although it rarely occurs through mutation of BRAF or RAS. Br J Cancer 92: 2032-2038, 2005.

94. Wagner EF and Nebreda AR: Signal integration by JNK and p38 MAPK pathways in cancer development. Nat Rev Cancer 9: 537-549, 2009.

95. O'Connell RM, Taganov KD, Boldin MP, Cheng G and Baltimore D: MicroRNA-155 is induced during the macrophage inflammatory response. Proc Natl Acad Sci USA 104: 1604-1609, 2007.

96. Mateescu B, Batista L, Cardon M, Gruosso T, de Feraudy Y, Mariani O, Nicolas A, Meyniel JP, Cottu P, Sastre-Garau X, et al: miR-141 and miR-200a act on ovarian tumorigenesis by controlling oxidative stress response. Nat Med 17: 1627-1635, 2011.

97. Shao N, Lu Z, Zhang Y, Wang M, Li W, Hu Z, Wang S and Lin Y: Interleukin-8 upregulates integrin $\beta 3$ expression and promotes estrogen receptor-negative breast cancer cell invasion by activating the PI3K/Akt/NF- $\mathrm{KB}$ pathway. Cancer Lett 364 : 165-172, 2015.
98. Yue S, Li J, Lee SY, Lee HJ, Shao T, Song B, Cheng L, Masterson TA, Liu X, Ratliff TL, et al: Cholesteryl ester accumulation induced by PTEN loss and PI3K/AKT activation underlies human prostate cancer aggressiveness. Cell Metab 19: 393-406, 2014.

99. Graham RM, Middleton A, Benito DA, Uddin R, Zhang B, Walters W, Bregy A, Vanni S and Komotar RJ: Targeting cancer stem cells via inhibition of PI3K/AKT pathway alone and in combination with autophagy blockade. Mol Cancer Ther 14: B39, 2015. doi: 10.1158/1538-8514.PI3K14-B39.

100. Prasad SB, Yadav SS, Das M, Modi A, Kumari S, Pandey LK, Singh S, Pradhan S and Narayan G: PI3K/AKT pathwaymediated regulation of $\mathrm{p} 27(\mathrm{Kip} 1)$ is associated with cell cycle arrest and apoptosis in cervical cancer. Cell Oncol (Dordr) 38: 215-225, 2015

101. Mabuchi S, Kuroda H, Takahashi R and Sasano T: The PI3K/ $\mathrm{AKT} / \mathrm{mTOR}$ pathway as a therapeutic target in ovarian cancer. Gynecol Oncol 137: 173-179, 2015.

102. Jin D, Yang JP, Hu JH, Wang LN and Zuo JL: MCP-1 stimulates spinal microglia via PI3K/Akt pathway in bone cancer pain. Brain Res 1599: 158-167, 2015.

103. Fang F, Wang L, Zhang S, Fang Q, Hao F, Sun Y, Zhao L, Chen S, Liao H and Wang L: CD147 modulates autophagy through the $\mathrm{PI} 3 \mathrm{~K} / \mathrm{Akt} / \mathrm{mTOR}$ pathway in human prostate cancer PC-3 cells. Oncol Lett 9: 1439-1443, 2015.

104. Cárdenas A, Kong M, Alvarez A, Valdivia A, Quest AF and Leyton L: PAR-3 and Syndecan-4 are involved in astrocyte adhesion induced by neuronal Thy-1 ocyte adhesion. Glia 63: E102-E102, 2015.

105.Xie M, He J, He C and Wei S: $\gamma$ secretase inhibitor BMS-708163 reverses resistance to EGFR inhibitor via the PI3K/Akt pathway in lung cancer. J Cell Biochem 116: 1019-1027, 2015.

106. Xue B, Huang W, Yuan X, Xu B, Lou Y, Zhou Q, Ran F, Ge Z, Li R and Cui J: YSY01A, a novel proteasome inhibitor, induces cell cycle arrest on G2 phase in MCF-7 cells via ER $\alpha$ and PI3K/ Akt pathways. J Cancer 6: 319-326, 2015.

107. Niu NK, Wang ZL, Pan ST, Ding HQ, Au GH, He ZX, Zhou ZW, Xiao G, Yang YX, Zhang X, et al: Pro-apoptotic and pro-autophagic effects of the Aurora kinase A inhibitor alisertib (MLN8237) on human osteosarcoma U-2 OS and MG-63 cells through the activation of mitochondria-mediated pathway and inhibition of p38 MAPK/PI3K/Akt/mTOR signaling pathway. Drug Des Devel Ther 9: 1555-1584, 2015.

108. Gatza ML, Watt JC and Marriott SJ: Cellular transformation by the HTLV-I Tax protein, a jack-of-all-trades. Oncogene 22: 5141-5149, 2003.

109. Bai XT and Nicot C: miR-28-3p is a cellular restriction factor that inhibits human T cell leukemia virus, type 1 (HTLV-1) replication and virus infection. J Biol Chem 290: 5381-5390, 2015.

110. Drosten M, Sum EY, Lechuga CG, Simón-Carrasco L, Jacob HK, García-Medina R, Huang S, Beijersbergen RL, Bernards R and Barbacid $\mathrm{M}$ : Loss of $\mathrm{p} 53$ induces cell proliferation via Ras-independent activation of the Raf/Mek/Erk signaling pathway. Proc Natl Acad Sci USA 111: 15155-15160, 2014.

111. Manousaridis I, Mavridou S, Goerdt S, Leverkus M and Utikal J: Cutaneous side effects of inhibitors of the RAS/RAF/MEK/ ERK signalling pathway and their management. J Eur Acad Dermatol Venereol 27: 11-18, 2013.

112. Noser JA, Sakuma R, Lee PWK and Ikeda Y: The Ras/Raf-1/ MEK/ERK signaling pathway dictates host cell permissiveness to VSV infection. Mol Ther 13: S371-S371, 2006.

113. Dancey JE: Agents targeting ras signaling pathway. Curr Pharm Des 8: 2259-2267, 2002. 